\title{
Spillover Effects of Foreign Direct Investment Inflows and Exchange Rates on the Banking Industry in China
}

\author{
Jung Wan Lee ${ }^{1}$, Zhen Wang ${ }^{2}$
}

Received: December 27, 2017. Revised: March 31, 2018. Accepted: May 5, 2018.

\begin{abstract}
The study examines the magnitude of economic spillover and the impact of foreign direct investment (FDI) inflows on the efficiency of the bank industry in China. This study employs unit root tests, cointegration tests and cointegrating regression analysis, including fully modified ordinary least squares (FMOLS), canonical cointegrating regression (CCR) and dynamic OLS (DOLS) to test the proposed hypotheses. The sample is restricted to the period of time in which monthly data is available and comparable among variables for the period from January 2002 to October 2013 (142 observations). All of the time series data was collected and retrieved from the People's Bank of China, China Monthly Statistics from the National Bureau of Statistics of China, and International Financial Statistics database from International Monetary Fund. The results of the Johansen cointegration test suggest that there is a long-run equilibrium relationship between FDI inflows, foreign exchange rate and banks performance in China. The results of cointegrating regression analysis using FMOLS, CCR and DOLS suggest that M2 supply and FDI inflows are significant at the 0.01 level. The results confirm that FDI inflows in the banking sector are positively related to the increase of banks productivity and performance and short-term loans in China. However, the results suggest that Chinese Yuan currency exchange rate to U.S. dollar is not significant in the banking and financial industry of China.
\end{abstract}

Keywords: Foreign direct investment, Exchange rate, Economic spillover, Bank productivity, Bank performance, Banking industry, China.

JEL Classification Code: E42, E43, E51, E52, G21.

\section{Introduction}

The past decade was marked by the increasing role of foreign direct investment (FDI), since the World Trade Organization (WTO) approved the text of the agreement for China's entry into WTO on December 11, 2001 and China officially became a member of WTO 30 days after that day. In 2011, the actual inflow of foreign investment was up to 116 billion U.S. dollars, increased by $252 \%$ comparing with 2001 (National Bureau of Statistics of China). The average annual growth rate of foreign investment inflow in last ten years was more than 10 percent. Meanwhile, as an essential part of economic development, China has speeded up the pace of reform in banking industry and

1 First Author and Corresponding Author, Administrative Sciences Department, Metropolitan College, Boston University, United States. [Postal Address: 808 Commonwealth Avenue, Boston, MA 02215, United States] E-mail: jwlee119@bu.edu

2 Administrative Sciences Department, Metropolitan College, Boston University, United States. E-mail: janewang@bu.edu encouraged a variety of foreign institutions to invest and operate in China. Since 2006, China has removed the geographic and clientele restrictions on RMB business for foreign banks, more and more foreign financial service companies entered into China in different ways. By the end of 2012, 42 foreign banks operated as independently capitalized subsidiaries affiliated by 95 branches, 197 representatives and more than 900 outlets in Mainland China (China Bank Regulatory Commission). As a result, how the FDI influence the efficiency of Chinese bank sector has been on the forefront of economic discussion among policy makers and scholars.

Foreign direct investment (FDI) is defined as investment to obtain a lasting management interest $(10 \%$ or more of voting stock) in an enterprise operating in an economy other than that of the investor. In the literature there exists some research suggesting mixed results of pros and cons of FDI from a view of domestic banking industry. Several benefits of FDI have been identified but are not limited as production efficiency (Yao \& Wei, 2007), technological spillovers, management techniques, international trade integration (Agbloyor, Abor, Adjasi, \& Yawson, 2013) and introduction 
of new products or process to domestic market (Alfaro, Chanda, Kalemli-Ozcan, \& Sayek, 2004). Even though the FDI in bank sectors doesn`t always result in higher profits, major domestic banks do display benefits from technical and management efficiency after they strategy alliance with world-leading foreign banks. On the other hand, foreign banks entry, as a major source of FDI in bank sector, will definitely create a more competitive market environment, which may take over the market share of domestic banks. Deng, Guo and Kong (2011) indicated that foreign entry could cause operation costs and profits of domestic banks to rise if the host economy is relatively undeveloped. A higher opening degree of a country`s financial market, to some extent, will contain more unstable factors from foreign bank presence. When faced with capital or funding shock, such as 2008 financial crisis, uncertainty have been raised from foreign banks withdraw from oversea banking business and reduce credit extension in host country.

In 2008, as the international financial crisis extent from United States to European, and finally touched the major emerging economies such as China. Depression of host markets resulted in a temporarily shrink of business activity in China and a loss of consumer confidence for foreign banks. Most clients turned to domestic commercial banks after 2008 seeking a more safety financial service. However, some evidences have been found in the previous literature that financial crisis may also stimulate a new wave of foreign investment inflows. Alfaro et el. (2004) showed that following the debt crisis in the 1980s, developing countries have changed their attitude towards FDI because they believed that FDI could contribute to the development efforts of a country. How did the financial crisis in 2008 affect the relationship between foreign investment inflows and the banking efficiency in Mainland China? It is still a mysterious and significant question to answer.

The objective of this paper is to provide additional evidence on the spillover effects of FDI inflows to the banking sector in Mainland China. More precisely, we attempt to fill the gap in the literature by investigating how information is transmitted between these two economic variables through short-term price interactions and volatility spillovers. Unlike most studies this paper would benefit the literature in three aspects. First this study analyzes the longterm linkage between FDI in bank sector and efficiency spillover of Chinese banking industry by using cointegration test. This could offer an academic evidence for Chinese government to forward financial market opening-up reform in the next few decades and manage the foreign direct investment more efficiently. Second, the paper empirically explores the short-term dynamic relationships between these two variables using Granger causality tests, which can help business owners and foreign investors to make better short-term informed investment and financing decisions. In addition, applying financial crisis in 2008 as a dummy variable, the current paper examines the impact of global market shock on the linkage between FDI and spillover efficiency of banking industry.

\section{Literature Review}

\subsection{Overview of Chinese Banking System}

Chinese banking system, after experiencing 30 years reform process since 1978, has become a critical role in supporting the rapid economic growth of China. The central bank, People's Bank of China (PBOC), was founded in 1948 splitting its commercial function and lending function since 1978. Comparing with 34 years ago. Chinese banking industry controlling the big part of total asset and providing more than three fifths of total credit to the private sector is now in gradually diversification and transparency. There are many types of banking institutions now in China. According to China Banking Regulatory Commission 2012 annual report, by the end of 2012, China's banking sector consisted of 2 policy banks, 5 large commercial banks, 12 joint-stock commercial banks, 144 city commercial banks, 337 rural commercial banks, 147 rural cooperative banks, 1927 rural credit cooperatives (RCCs), one postal savings bank, 4 banking assets management companies, 42 locally incorporated foreign banking institutions, 67 trust companies, 150 finance companies of corporate groups, 20 financial leasing companies, 800 village or township banks, 14 lending companies and 49 rural mutual cooperatives. Overall, the number of banking institutions in China's banking sector amounted to 3747 with 3362 million employees. If we breakdown the entire financial market into four parts: commercial bank, securities firm, insurance company and others, commercial banks dominate around 90 percent of the financial industry total assets.

Looking deeply at all the commercial banks in China, the big five state-own commercial banks and 12 joint-stocks commercial banks take a big market share comparing with other city commercial banks. Following the develop strategy of the big five state-owned banks (Bank of China, China Construction Bank, Industrial and Commercial Bank of China, Agricultural Bank of China and China Bank of Communication), more and more banks in China prefer to engage with foreign banks and absorbed foreign capital in last decade. For example, in 2005, Bank of Nanjing accepted BNP Paribas as its strategic partner and second largest shareholder. In 2007, Industrial Bank signed a strategy alliance agreement. In 2011, they signed another 
agreement about keep corporate relationship in asset management, private bank etc. As measured by China Banking Regulatory Commission (CBRC) at the end of 2011, 25 foreign institutions cooperated with 27 Chinese banks as strategy investors. However, do the foreign investors cause the efficiency spillover of bank sectors? The answers are quite mixed.

\subsection{Banking Efficiency}

Previous studies have addressed different measurements of bank efficiency. Fixler and Zieschange (1993) measured banking technical efficiency by using a superlative index number approach. Lee and Hsieh (2013) included four different profitability variables: return on assets (ROA), return on equity (ROE), net interest margin (NIM) and net interest revenue against average assets (NR) for a study of Asia bank efficiency. The study showed that different profitability variables have different results on the persistence of profit and more specifically, ROA and ROE do not show persistence of profit, but NIM and NR do. Lee and Hsieh (2013) also confirmed with robustness tests that regulatory quality and institutional development are independent of differences in profitability and risk in Asia. Berger, Hasan, and Zhou (2009) believed that the efficiency measures how close to the minimum cost or maximum profit a bank is. Total loan, total deposit and fixed assets were also widely used to measure bank efficiency (Berger et al., 2009; Lin, Tsao, \& Yang, 2009; Ye, Xu, \& Fang, 2012), bank productivity (Matthews \& Zhang, 2010), cost efficiency (Chen, Skully, \& Brown, 2005; Fu \& Heffernan, 2007) and profit efficiency (Ariff \& Can, 2008; Deng et al., 2011) in China. Agbloyor et al. (2013) utilized private credit, bank credit and M2 as the indicators of bank sector development when studying of Africa countries.

Is there an efficiency difference among different types of Chinese bank? Berger et al. (2009) suggested that the large state-owned banks are least efficient, but foreign banks are most efficient. Chen et al. (2005) indicated that the large state-owned commercial banks and smaller banks are more efficient than medium sized Chinese bank in terms of the deregulation program in 1995. More specifically, Yao, Han and Feng (2008) indicated that the three large state-owned banks (including China Construction Bank, Bank of China and Industrial and Commercial Bank of China) show a higher technical efficiency and profitability, which explain why their IPOs in 2005 and 2006 were so heavily demanded by investors. However, some researcher found that the joint stock banks perform significantly better than both the state banks and the city commercial banks (Shih, Zhang, \& Liu 2007; Ariff \& Can, 2008; Fu \& Heffernan, 2007). In the current study, we will examine the spillover effect of the
Chinese bank sector as a whole including the large-size, medium-size and small size banks in mainland China by using total loan, total deposit, loan to deposit (LTD) as the main variables.

Besides banks scale, There are some other factors, which could influence the Chinese bank efficiency, such as region, law enforcement and risk level. Zhou, Li, and Li (2011) found that technical efficiency of banks seems to be higher in both Eastern and Southern regions than the national average level. They pointed out that even though China has put more effort on the development of the western region, its technical efficiency has remained low. Similarly, Yao and Wei (2007) indicated that human capital, transportation, export and FDI have limited effect on production in the west region even though FDI may influence a little on its technological progress. Zhang, Wang, and Qu (2012) indicated that Chinese city banks show a better performance and higher efficiency in a better legal environment. Tan and Floros (2013) found a positive relationship between risk (LLPTL) and pure technical efficiency of Chinese banks.

\subsection{Foreign Direct Investment and Bank Efficiency Spillover}

The main FDI characteristic and entry mode have been found out in previous literature (Fan, Morck, Xu, \& Yeung, 2009; Xing, 2006; Lin, Liu \& Zhang, 2009). Hsiao and Hsiao (2004) indicated that Hong Kong and Taiwan dominate $40 \%$ to $60 \%$ percent of the total FDI, followed by the United States and EU. And almost all the FDI were concentrated in the eastern region, especially in these five cities: Shenzhen, Xiamen, Qingdao, Dalian and Ninbo. Li, Zeng, and Zhang (2013) theoretically explained some stylized facts about foreign entry mode. First, foreign subsidiaries and branches cluster in the eastern China or in the large (central cities); Second, foreign banks without strong financial strength and competitiveness advantage tend to take stakes (jointventure or strategy alliance) in the domestic banks; Third, foreign banks with strong financial strength will set up subsidiaries or branches accompanied with cooperation with domestic banks (Li et al., 2013).

In the previous literature there exist some studies suggesting mixed results about the efficiency spillover from Foreign Direct Investment in cross-countries or individual countries such as Poland (Degryse, Havrylchyk, Jurzyk, \& Kozak, 2012), Australia (Sturm \& Williams, 2004), Africa (Agbloyor et al., 2013). Their studies indicated that the foreign bank entry, as the main source of FDI in bank sector can cause the spillovers of banking efficiency. By using cross-country data between 1975 and 1995, the empirical analysis from Alfaro et al. (2004) showed that countries with 
well-developed financial markets gain significantly from FDI. Azman-Saini, Law and Ahmad (2010) agreed that the positive effect of FDI on growth "kick in" only after financial markets development exceeds a threshold level. Also, FDI inflows had a non-linear effect on growth, they were growth enhancing in developing countries and there is a 'tworegime' FDI effect for high-income economies (Kottaridi \& Stengos, 2010). On the contrary, Lensink and Hermes (2004) argued that FDI in bank sector might have a stronger effect on domestic banks in terms of the spillover of modern bank techniques and practices in lower levels of economic development because of the gap between development of domestic and foreign banking. Degryse et al. (2012) analyzed the impact of foreign bank entry on the supply of loans and portfolio quality of domestic banks in Poland and found that the entry of Greenfield foreign banks encourages domestic banks to increase the share of entrepreneurs in their portfolios. As a result, the higher competition from foreign bank entry forced domestic banks to lend money for riskier firms.

After taking a global viewpoint based on the panel data approach, Lee and Chang (2009) examined the long-run comovements and the causal relationships among FDI, financial development, and economic growth in a multivariate model and found a clear sign of bi-directional causal linkages among these variables. More specifically, Lee and Chang (2009) also found a bi-directional causal relationship between FDI and the financial development, which offered a theoretical evidence for our current studies.

In terms of Chinese bank industry, there has been a considerable amount of empirical work on the FDI impact on bank spillover of bank efficiency. Deng et al. (2011) suggested that the presence of foreign banks improved the overall profitability of the Chinese banks and has also effectively constrained the scaled of loan. They summarized several channels about efficiency spillovers of foreign banks: enforced competition, demonstrated effect in high-end business, expert turnovers from foreign banks to domestic banks, improved corporate governance in collaboration with strategic investors, and financial innovation techniques introduced by foreign shareholders (Deng et al., 2011). Other studies also made a similar conclusion that FDI inflow creates a more competitive and more efficient banking industry in Mainland China in the way of margin and cost (Xu, 2011; Jiang Yao \& Zhang, 2009; Lin et al., 2009). Specially, Jiang et el. (2009) went further step to prove that foreign acquisition could benefit domestic banks by efficiency gains in the long-term, but privatization via initial public offerings (IPOs) just have a short-term effects. Lin et al. (2009) tested the impact of WTO and restrictions on foreign entry on the Chinese bank industry and evidence have been found that the efficiency score for the post WTO accession period is significantly higher than that for the preWTO accession period.

\subsection{Empirical Model and Hypotheses}

Total factor productivity is the portion of output not explained by traditionally measured inputs of labor and capital used in production. As such, its level is determined by how efficiently and intensely the inputs are utilized in production. The equation below (in Cobb-Douglas form) represents total output $(\mathrm{Y})$ as a function of total factor productivity $(A)$, capital input $(K)$, labor input $(L)$, and the two inputs' respective shares of output ( $\alpha$ and $\beta$ are the share of contribution for $K$ and $L$ respectively). An increase in either $A, K$ or $L$ will lead to an increase in output.

$$
Y=A \times K^{\alpha} \times L^{\beta}
$$

This study aims to examine the impact of foreign direct investment inflows and foreign exchange rate on banks productivity and performance in China. Accordingly, the following hypotheses are considered:

\footnotetext{
$<$ Hypothesis $1>$ There is a long-run equilibrium relationship between foreign direct investment inflows, foreign exchange rate and banks performance.

$<$ Hypothesis 2> M2 supply is related to banks productivity and performance in the short-run.

$<$ Hypothesis $3>\mathrm{CPI}$ is related to banks productivity and performance in the short-run.

$<$ Hypothesis $4>$ Lending interest rate is related to banks productivity and performance in the short-run.

$<$ Hypothesis 5> Foreign direct investment inflows are related to banks productivity and performance in the short-run.

$<$ Hypothesis $6>$ Foreign exchange rate is related to banks productivity and performance in the short-run.
}

\section{Research Methodology}

\subsection{Data and Indicators}

The sample is restricted to the period of time in which monthly data is available and comparable among variables for the period from January 2002 to October 2013 (142 observations). All of the time series data below was collected and retrieved from the People's Bank of China, China Monthly Statistics from the National Bureau of Statistics of China, and International Financial Statistics database from International Monetary Fund.

Short-term Loans: A short-term loan refers to a loan scheduled to be repaid in less than a year. Typically, short- 
term loans offer fast funding, but with high interest rates and quick payback. When a business doesn't qualify for a line of credit from a bank, the business might still have success in obtaining money from then in the form of a short-term loan (i.e., less than a year) to finance its temporary working capital needs.

Deposit: A deposit is the monetary amount that is placed with some entity. The deposit is a credit for the party individual or organization - who placed it, and it may be taken back (i.e. withdrawn), transferred to some other party, or used for a purchase at a later date. This financial concept is often used with respect to banks, where deposits are usually their main source of funding. The deposit can be one of two things: first, a transaction involving a transfer of funds to another party for safekeeping, and second, a portion of funds that is used as security or collateral for the delivery of a good. The first type of deposit is identical to the money an investor transfers into a bank's savings or checking accounts. It can be made by individuals or entities such as corporations. The money is still owned by the person or entity that deposited the money, and it can be withdrawn at any time, transferred to another person's account, or used to purchase goods. Often, a person must deposit a certain amount of money in order to open a new bank account, which is known as a minimum deposit. This amount covers the costs associated with opening and maintaining the account.

Loan-To-Deposit Ratio (LTD): The loan-to-deposit ratio is a commonly used statistic for assessing a bank's liquidity by dividing the bank's total loans by its total deposits. This number is expressed as a percentage. If the ratio is too high, it means that the bank may not have enough liquidity to cover any unforeseen fund requirements, and conversely, if the ratio is too low, the bank may not be earning as much as it could be. To calculate LTD ratio, take the total amount of loans granted by a bank over a specific period of time and divide by the amount of deposits received by the bank over the same period.

Money and Quasi Money (M2): Money and quasi money comprise the sum of currency outside banks, demand deposits other than those of the central government, and the time, savings, and foreign currency deposits of resident sectors other than the central government. M2 is a measure of the money supply that includes all elements of M1 as well as near money. M1 includes cash and checking deposits, while near money refers to savings deposits, money market securities, mutual funds and other time deposits. These assets are less liquid than $\mathrm{M} 1$ and not as suitable as exchange mediums, but they can be quickly converted into cash or checking deposits. The money supply measures the amount of monetary assets available in an economy. This is an important metric in macroeconomics, because it can dictate inflation and interest rates. Inflation and interest rates have major ramifications for the general economy, as these heavily influence employment, consumer spending, business investment, currency strength and trade balances.

Consumer Price Index (CPI): A consumer price index measures changes in the price level of market basket of consumer goods and services purchased by households. The CPI is a statistical estimate constructed using the prices of a sample of representative items whose prices are collected periodically. Sub-indices and sub-sub-indices are computed for different categories and sub-categories of goods and services, being combined to produce the overall index with weights reflecting their shares in the total of the consumer expenditures covered by the index. The annual percentage change in a $\mathrm{CPI}$ is used as a measure of inflation. A CPI can be used to index (i.e., adjust for the effect of inflation) the real value of wages, salaries, pensions, for regulating prices and for deflating monetary magnitudes to show changes in real values. In most countries, the CPI, along with the population census, is one of the most closely watched national economic statistics.

Lending Interest Rate (\%): The lending rate is the bank rate that usually meets the short- and medium-term financing needs of the private sector. This rate is normally differentiated according to creditworthiness of borrowers and objectives of financing. The terms and conditions attached to these rates differ by country, however, limiting their comparability. It is defined as the proportion of an amount loaned which a lender charges as interest to the borrower, normally expressed as an annual percentage. It is the rate a bank or other lender charges to borrow its money.

Foreign Direct Investment (FDI), net inflows (BOP, current US\$): Foreign direct investment are the net inflows of investment to acquire a lasting management interest (10 percent or more of voting stock) in an enterprise operating in an economy other than that of the investor. It is the sum of equity capital, reinvestment of earnings, other long-term capital, and short-term capital as shown in the balance of payments. This series shows total net FDI. In BPM6, financial account balances are calculated as the change in assets minus the change in liabilities. Net FDI outflows are assets and net FDI inflows are liabilities. Data are in current U.S. dollars.

\subsection{Descriptive Statistics of Data}

All these time series data have been collected and retrieved from various reports from the People's Bank of China, China Monthly Statistics from the National Bureau of Statistics of China, and International Financial Statistics database from International Monetary Fund. For all these time series data are reported on a monthly basis and 
employed for the period from January 2002 to October 2013 (142 observations). Table 1 displays descriptive statistics along with various summary statistics for the time series. Table 2 displays the results of Pearson correlation analysis between the time series.

Table 1. Descriptive Statistics of Banking and Financial Industry of Chain (Monthly, 2002-2013)

\begin{tabular}{|c|c|c|c|c|c|}
\hline & Unit & Minimum & Maximum & Mean & $\begin{array}{c}\text { Std. } \\
\text { Deviation }\end{array}$ \\
\hline $\begin{array}{c}\text { Short-term } \\
\text { Loans }\end{array}$ & 100 million Yuan & 66508 & 280494 & 133751 & 58736 \\
\hline Deposits & 100 million Yuan & 143388 & 1030891 & 478289 & 267048 \\
\hline $\begin{array}{c}\text { Loan-To- } \\
\text { Deposit Ratio }\end{array}$ & $\%$ & .63 & .78 & .69 & .04 \\
\hline M2 & 100 million Yuan & 157853 & 1077379 & 492516 & 276833 \\
\hline CPI & Index & 98.20 & 108.70 & 102.63 & 2.39 \\
\hline Lending Rate & $\%$ & 5.31 & 7.47 & 5.88 & .65 \\
\hline FDI ${ }^{1)}$ & 100 million Yuan & 1 & 606 & 73 & 94 \\
\hline Forex(USD) & Yuan & 6.15 & 8.28 & 7.35 & .80 \\
\hline
\end{tabular}

1) Foreign direct investment net inflows in the financial industry of China. The data was retrieved from China Monthly Statistics from the National Bureau of Statistics of China.

Source: The authors have compiled data from various reports from the People's Bank of China, China Monthly Statistics from the National Bureau of Statistics of China, and International Financial Statistics database from International Monetary Fund.

Table 2. Pearson Correlations

\begin{tabular}{|c|c|c|c|c|c|}
\hline & $\begin{array}{c}\text { Short } \\
\text { Loans }\end{array}$ & M2 & CPI & $\begin{array}{c}\text { Lending } \\
\text { Rate }\end{array}$ & FDI \\
\hline M2 & $.989^{* *}$ & & & & \\
\hline CPI & $.223^{* *}$ & $.242^{* *}$ & & & \\
\hline Lending Rate & $.279^{* *}$ & $.277^{* *}$ & $.729^{* *}$ & & \\
\hline FDI & $.615^{* *}$ & $.611^{* *}$ & $.176^{*}$ & $.188^{*}$ & \\
\hline Forex & $-.912^{* *}$ & $-.947^{* *}$ & $-.306^{* *}$ & $-.393^{* *}$ & $-.546^{* *}$ \\
\hline
\end{tabular}

Correlation is significant ${ }^{*}$, at the 0.05 level and ${ }^{* *}$, at the 0.01 level (2-tailed).

\subsection{Unit Root Test}

It is well known in the literature that the data generating process for many economic variables are characterized by stochastic trends that might result in spurious inference if the time series properties are not carefully investigated. A time series is said to be stationary if the mean and autocovariances of the series do not depend on time. Any series that is not stationary is said to be non-stationary (i.e. it has a unit root). The formal method to test the stationarity of a series is the unit root test. There are several well-known tests for this purpose based on individual time series: the augmented Dickey-Fuller (ADF) unit root test (Dickey \& Fuller, 1979, 1981), the Phillips-Perron (PP) unit root test
(Phillips \& Perron, 1988), and the Kwiatkowski, Phillips, Schmidt and Shin (KPSS) unit root test (Kwiatkowski, Phillips, Schmidt, \& Shin, 1992), among others.

Table 3 reports the results of unit root tests. All test equations were tested by the method of least squares, including an intercept but no time trend in the model. Probabilities for all tests assume asymptotic normality. In the ADF and PP tests, an optimal lag in the tests is automatically selected based on Schwarz Info Criterion and the lag length (bandwidth) in the tests is automatically selected based on the Newey-West estimator (Newey \& West, 1994) using the Bartlett kernel function. In ADF and PP tests, probability values for rejection of the null hypothesis of a unit root are employed at the 0.05 level based on MacKinnon (1996) one-sided p-values. KPSS tests the null hypothesis: the series has no unit root (the series is stationary), while the alternative hypothesis assumes that the series has a unit root (non-stationary). In KPSS test, probability values for rejection of the null hypothesis are based on Kwiatkowski et el. (1992) LM statistic p-values.

Table 3. Results of Unit Root Tests

\begin{tabular}{|c|c|c|c|c|c|c|}
\hline Tests & ADF(0) & ADF(1) & PP(0) & PP(1) & KPSS(0) & KPSS(1) \\
\hline Short Loans & 3.120 & $-10.122^{* *}$ & 2.906 & $-10.344^{* *}$ & $1.362^{* *}$ & 0.374 \\
\hline M2 & -0.420 & $-9.149^{* *}$ & -0.649 & $-13.155^{* *}$ & $1.396^{* *}$ & 0.108 \\
\hline CPI & -1.792 & $-5.276^{* *}$ & -1.602 & $-11.145^{* *}$ & $0.639^{*}$ & 0.254 \\
\hline Lending Rate & -2.181 & $-8.094^{* *}$ & -1.989 & $-8.261^{* *}$ & $0.661^{*}$ & 0.261 \\
\hline FDI & -0.841 & $-6.790^{* *}$ & -1.635 & $-6.735^{* *}$ & $0.998^{* *}$ & 0.095 \\
\hline Forex & -0.089 & $-3.699^{* *}$ & -0.367 & $-9.703^{* *}$ & $1.344^{* *}$ & 0.225 \\
\hline
\end{tabular}

The numeric values in cells are t-statistic.

Probability values for rejection of the null hypothesis are employed at the $5 \%$ significant level $\left({ }^{*}\right.$, p-value $<0.05$ and ${ }^{* *}$, p-value $\left.<0.01\right)$.

\section{Results}

\subsection{Cointegration Test}

Engle and Granger (1987) point out that a linear combination of two or more non-stationary series may be stationary. If such a stationary linear combination exists, the non-stationary time series are said to be cointegrated. If these variables are cointegrated, then there exists long-run equilibrium among the variables. In other words, if the variables are cointegrated, there is a long-run relationship, and there exists a force to converge into long-run equilibrium. There are two test methods to identify whether there is a long-run relationship among variables: the EngleGranger single equation test method (Engle \& Granger, 1987 ) and the Johansen conintegration test (Johansen, 1988). 
Cheung and Lai (1993) report that the Johansen approach is more efficient than the Engle-Granger single equation test method because the maximum likelihood procedure has useful large and finite sample properties. The Johansen cointegration test models each variable as a function of all the lagged endogenous variables in the system. The Johansen procedure uses two ratio tests: a trace test and a maximum eigenvalue test, to test the number of cointegration relationships. Both tests can be used to determine the number of cointegrating vectors present, although they do not always indicate the same number of cointegrating vectors. If trace statistics and maximum eigenvalue statistics yield different results, the result of the maximum eigenvalue test is preferred due to the benefit of carrying out separate tests on each eigenvalue.

Table 4 reports the results of the Johansen cointegration test. The test equation was tested by the method of least squares. The regression model allows for a linear deterministic trend in data and includes intercept but no trend in vector autoregressive models. For the two likelihood ratio test statistics, the probability value for rejection of the null hypothesis of no cointegration is based on the MacKinnon, Haug and Michelis (1999) p-values. The null hypothesis of no cointegration is rejected at the $5 \%$ significance level. The trace test indicates at least one cointegrating equation exists at the 0.05 level, and the maximum eigenvalue test also indicates at least one cointegrating equation exists at the 0.05 level. Therefore, the null hypothesis of no cointegration can be rejected at the 0.05 level. Considering the results of the Johansen cointegration test in Table 4, this study concludes that hypothesis 1 that there is a long-run equilibrium relationship between foreign direct investment inflows, foreign exchange rate and banks performance in China, is supported.

Table 4. Results of Johansen Cointegration Test

\begin{tabular}{|c|c|c|}
\hline $\begin{array}{c}\text { Number of cointegration } \\
(\boldsymbol{r})\end{array}$ & Trace statistic & $\begin{array}{c}\text { Maximum eigenvalue } \\
\text { statistic }\end{array}$ \\
\hline$r=0$ & $100.148^{* *}$ & $44.803^{*}$ \\
\hline$r \leq 1$ & 55.345 & 24.517 \\
\hline$r \leq 2$ & 30.828 & 15.927 \\
\hline$r \leq 3$ & 14.901 & 8.664 \\
\hline$r \leq 4$ & 6.237 & 5.961 \\
\hline$r \leq 5$ & 0.275 & 0.275 \\
\hline
\end{tabular}

Regression model: Short-term Loans $=$ M2 + CPI + Lending Rate + FDI + Forex

The numeric values in cells are trace statistic and maximum eigenvalue statistic.

Cointegrating equations are significant at the 0.05 level $\left({ }^{*}, \mathrm{p}\right.$-value $<$ 0.05 and ${ }^{* *}$, p-value $<0.01$ ).

\subsection{Cointegrating Regression Analysis}

Considering the results of the Johansen cointegration test in Table 4, it is evident that there is a long-run equilibrium relationship between TFP growth factors and total output in Pakistan. In this case, an unrestricted vector autoregressive model would not be an effective option for testing short-run dynamics. Engle and Granger (1987) noted that if two or more time series variables are cointegrated, there is always a corresponding error correction representation in which the short-run dynamics of the variables in the system are influenced by the deviation from equilibrium. The cointegrated variables must have an error correction representation in which an error correction term is incorporated into the model. In this case, a vector error correction model is formulated to reintroduce the information lost in the differencing process, thereby allowing for long-run equilibrium as well as short-run dynamics. The vector error correction model implies that changes in one variable are a function of the level of disequilibrium in the cointegrating relationship (i.e., captured by the error correction term), as well as changes in other explanatory variables. There are several estimation methods for testing a single cointegrating vector, an error correction term. These are fully modified OLS (Phillips \& Hansen, 1990), canonical cointegrating regression (Park, 1992), and dynamic OLS (Saikkonen, 1992; Stock \& Watson, 1993).

Phillips and Hansen (1990) propose an estimator that employs a semi-parametric correction to eliminate the problems caused by the long-run correlation between the cointegrating equation and stochastic regressor innovations. The Fully Modified OLS (FMOLS) estimator is asymptotically unbiased and has fully efficient mixture normal asymptotics allowing for standard Wald tests using asymptotic Chi-square statistical inference (Hansen, 2002). The FMOLS estimator employs preliminary estimates of the symmetric and one sided long-run covariance matrices of the residuals. The canonical cointegrating regression (Park, 1992) is closely related to FMOLS, but instead employs stationary transformations of the data to obtain least squares estimates to remove the long-run dependence between the cointegrating equation and stochastic regressor innovations. Like FMOLS, the canonical cointegrating regression (CCR) estimates follow a mixture normal distribution, which is free of non-scalar nuisance parameters and permits asymptotic Chi-square testing. The CCR transformations asymptotically eliminate the endogeneity caused by the long-run correlation of the cointegrating equation errors and the stochastic regressor innovations, and simultaneously correct for asymptotic bias resulting from the contemporaneous correlation between the regression and stochastic regressor errors (Park, 1992). 
Estimates based on CCR are therefore fully efficient and have the same unbiased, mixture normal asymptotics as FMOLS (Park, 1992).

Saikkonen (1992) and Stock and Watson (1993) propose a simple approach to constructing an asymptotically efficient estimator that eliminates the feedback in the cointegrating system. The Dynamic OLS (DOLS) method involves augmenting the cointegrating regression with lags and leads of $\Delta X_{t}$ so that the resulting cointegrating equation error term is orthogonal to the entire history of the stochastic regressor innovations. The model employs an intercepttrend specification for the cointegrating equation, with no additional deterministics in the regressor equations, and four lags and leads of the differenced cointegrating regressor to eliminate long-run correlation between the innovations. Under the assumption that adding lags and leads of the differenced regressors soaks up all of the long-run correlation between long-run variances, least-squares estimates of the equation have the same asymptotic distribution as those obtained from FMOLS and CCR (Saikkonen, 1992; Stock \& Watson, 1993).

Table 5. Results of Cointegrating Regression Analysis

\begin{tabular}{|c|c|c|c|}
\hline Estimation Method & FMOLS & CCR & DOLS \\
\hline M2 & $0.520(0.087)^{\star *}$ & $0.524(0.086)^{\star *}$ & $0.467(0.087)^{\star *}$ \\
\hline $\mathrm{CPI}$ & $0.409(0.766)$ & $0.371(0.751)$ & $0.631(0.761)$ \\
\hline Lending Rate & $-0.015(0.028)$ & $-0.015(0.029)$ & $-0.008(0.031)$ \\
\hline FDI & $0.036(0.012)^{\star \star}$ & $0.039(0.014)^{\star *}$ & $0.043(0.018)^{*}$ \\
\hline Forex(USD) & $-0.757(0.472)$ & $-0.721(0.475)$ & $-0.962(0.447)^{\star}$ \\
\hline $\begin{array}{c}\text { Cointegrating equation } \\
\text { deterministics }\end{array}$ & $4.553(3.537)$ & $4.600(3.384)$ & $4.615(3.673)$ \\
\hline R-squared & 0.969 & 0.969 & 0.982 \\
\hline Adjusted R-squared & 0.968 & 0.967 & 0.977 \\
\hline Long-run Variance & 0.017 & 0.017 & 0.125 \\
\hline $\begin{array}{c}\text { Cointegration } \\
\text { Coefficient Diagnostic }^{1}\end{array}$ & $\begin{array}{c}1.287 \\
D F=119\end{array}$ & $\begin{array}{c}1.359 \\
D F=119\end{array}$ & $\begin{array}{c}1.256 \\
D F=119\end{array}$ \\
\hline Cointegration Test $^{2}$ & $2.057^{\star *}$ & $1.845^{\star *}$ & 0.010 \\
\hline
\end{tabular}

Regression model: Short-term Loans $=\mathrm{M} 2+\mathrm{CPI}+$ Lending Rate + $\mathrm{FDI}(+/-)+$ Forex(+/-)

Probability values for rejection of the null hypothesis are employed at the $5 \%$ significant level $\left({ }^{*}, p\right.$-value $<0.05$ and ${ }^{* *}$, p-value $\left.<0.01\right)$. The numeric values in cells are coefficients of regressors and standard errors follow in parenthesis.

${ }^{1}$ Cointegration coefficient diagnostic test has been conducted by Wald test.

${ }^{2}$ Cointegration test has been conducted by Hansen parameter instability test for the null hypothesis (null hypothesis: series are cointegrated).

Table 5 reports the results of cointegrating regression analysis using FMOLS, CCR and DOLS. In testing hypothesis 2 that M2 supply is related to banks productivity and performance in the short-run, Table 5 shows that M2 supply is significant at the 0.01 level. The results confirm that M2 supply is positively related to the increase of shortterm loans in China.

In testing hypothesis 3 and 4 that $\mathrm{CPI}$ and lending interest rate are related to banks productivity and performance in the short-run, Table 5 shows that CPI and lending rate are not significant in China.

In testing hypothesis 5 that FDI inflows are related to banks productivity and performance in the short-run, Table 5 shows that FDI inflows are significant at the 0.01 level. The results confirm that FDI inflows in the banking sector are positively related to the increase of short-term loans in China.

In testing hypothesis 6 that foreign exchange rate is related to banks productivity and performance in the shortrun, Table 5 shows that Chinese Yuan currency exchange rate to USD is not significant in the banking and financial industry of China.

\section{Discussion and Policy Implication}

According to the analysis of the data above, this study yields some major findings. It sought to examine the impact of foreign direct investment inflows and foreign exchange rate on banks productivity and performance in China and discussed the relationships several factors might have with the productivity and performance of banking industry. Accordingly, our baseline results suggest that there is indeed a long-run equilibrium relationship between foreign direct investment inflows, foreign exchange rate and banks performance in China. Moreover, the M2 supply is positively related to the increase of short-term loans in China, and at the same time, the results confirm that FDI inflows in the banking sector are positively related to the increase of shortterm loans in China. On the contrary, tests show that CPI and lending rate are not significant in China and Chinese Yuan currency exchange rate to USD is also not significant in the banking and financial industry of China.

This study benefits the literature of FDI and performance of banking system in China in several ways. Firstly, it could academically support the government to facilitate the country's financial market. Secondly, entrepreneurs and global investors may benefit from the study by making better short-term informed investment and financing decisions. As important financial sectors in China, banks are supposed to create the right conditions for development of the effective and secure conversion of the savings of the population into the investment and local business financing, support the development of the financial markets by setting up regulations and institutions, attract the country to foreign investors who may bring additional financing and help accelerate the investment process and the economic growth 
of the country as end-effect and safeguard the financial system stability. Therefore, the practical policies to improve the performance and productivity of banks attract great attention. Some managerial implications for governments and banking management are clear based on our empirical results. Firstly, the government and central banks could adopt policy to increase the money supply, promote inflation within control and reduce interest rate. The intention is to create incentives for various kinds of investment and stimulate consumption, in which way to improve the performance and productivity of banking industry. Additionally, management could pay more attention to attract FDI into banking sectors such as to decrease or even eliminate the limits of entry of FDI and to allow qualified companies with FDI to issue their securities in the country's financial market.

\section{Conclusions and Research Limitations}

This paper focused on examining the impact of foreign direct investment inflows and foreign exchange rate on banks productivity and performance in China and discussed the relationships several factors might have with the productivity and performance of banking industry. The study has some theoretical implications on relevant literature and has also put forward with several managerial recommendations. However, our study still has limitations that may offer significant opportunities for future research on this important topic. Perhaps, future research is also needed more specifically on foreign direct investments themselves, to deeply figure out some problems and relationships such as what kinds of FDI benefit banking industry more in specific contexts.

\section{References}

Agbloyor, E. K., Abor, J., Adjasi, C. K. D., \& Yawson, A. (2013). Exploring the causality links between financial markets and foreign direct investment in Africa. Research in International Business and Finance, 28, 118-134.

Alfaro, L., Chanda, A., Kalemli-Ozcan, S., \& Sayek, S. (2004). FDI and economic growth: the role of financial markets. Journal of International Economics, 64(1), 89-112.

Ariff, M., \& Can, L. (2008). Cost and profit efficiency of Chinese banks: A non-parametric analysis. China Economic Review, 19(2), 260-273.

Azman-Saini, W. N. W., Law, S. H., \& Ahmad, A. H. (2010). FDI and economic growth: New evidence on the role of financial markets. Economic Letters, 107(2), 211-213.
Berger, A. N., Hasan, I., \& Zhou, M. (2009). Bank ownership and efficiency in china: What will happen in the world's largest nation?. Journal of Banking \& Finance, 33(1), 113-130.

Chen, X., Skully, M., \& Brown, K. (2005). Banking efficiency in china: Application of DEA to pre- and postderegulation eras: 1993-2000. China Economic Review, 16(3), 229-245.

Cheung, Y. W., \& Lai, K. S. (1993). Finite-sample sizes of Johansen's likelihood ratio tests for cointegration. Oxford Bulletin of Economics and Statistics, 55, 313328.

Degryse, H., Havrylchyk, O., Jurzyk, E., \& Kozak, S. (2012). Foreign bank entry, credit allocation and lending rates in emerging markets: Empirical evidence from Poland. Journal of Banking \& Finance, 36(11), 29492959.

Deng, Z., Guo, H., \& Kong, G. (2011). Efficiency spillovers of foreign direct investment in the Chinese banking system. Global Economic Review, 40(2), 179-191.

Dickey, D. A., \& Fuller, W. A. (1979). Distribution of the estimators for autoregressive time series with a unit root. Journal of the American Statistical Association, 74, 427-431.

Dickey, D. A., \& Fuller, W. A. (1981). Likelihood ratio statistics for autoregressive time series with a unit root. Econometrica, 49, 1057-1071.

Engle, R. F., \& Granger, C. W. J. (1987). Cointegration and error correction: Representation, estimation and testing. Econometrica, 55, 251-276.

Fan, J. P., Morck, R., Xu, L. C., \& Yeung, B. (2009). Institutions and foreign direct investment: China versus the rest of the world. World Development, 37(4), 852-865.

Fixler, D. J., \& Zieschang, K. D. (1993). An index number approach to measuring bank efficiency: An application to mergers. Journal of Banking and Finance, 17(2), 437-450.

Fu, X., \& Heffernan, S. (2007). Cost X-efficiency in china's banking sector. China Economic Review, 18(1), 35-53.

Hansen, B. E. (2002). Tests for parameter instability in regressions with I(1) processes. Journal of Business and Economic Statistics, 20(1), 45-59.

Hsiao, F. S., \& Hsiao, M. C. W. (2004). The chaotic attractor of foreign direct investment - Why China? A panel data analysis. Journal of Asian Economics, 15(4), 641-670.

Jiang, C., Yao, S., \& Zhang, Z. (2009). The effects of governance changes on bank efficiency in china: A stochastic distance function approach. China Economic Review, 20(4), 717-731. 
Johansen, S. (1988). Statistical analysis of cointegration vectors. Journal of Economic Dynamics and Control, 12, 231-254.

Kottaridi, C., \& Stengos, T. (2010). Foreign direct investment, human capital and non-linearities in economic growth. Journal of Macroeconomics, 32(3), 858-871.

Kwiatkowski, D., Phillips, P. C., Schmidt, P., \& Shin, Y. (1992). Testing the null hypothesis of stationary against the alternative of a unit root. Journal of Econometrics, 54, 159-178.

Lee, C. C., \& Chang, C. P. (2009). FDI, financial development, and economic growth: International evidence. Journal of Applied Economics, 12(2), 249271.

Lee, C. C., \& Hsieh, M. F. (2013). The impact of bank capital on profitability and risk in Asian banking. Journal of International Money and Finance, 32, 251281.

Lensink, R., \& Hermes, N. (2004). The short-term effects of foreign bank entry on domestic bank behaviour: Does economic development matter?. Journal of Banking \& Finance, 28(3), 553-568.

Li, Q., Zeng, Y., \& Zhang, B. (2013). Market characteristics and entry modes of foreign banks. China Economic Review, 24(1), 26-41.

Lin, H. L., Tsao, C. C., \& Yang, C. H. (2009). Bank Reforms, Competition and Efficiency in China`s Banking System: Are Small City Bank Entrants More Efficient?. China \& World Economy, 17(5), 69-87.

Lin, P., Liu, Z., \& Zhang, Y. (2009). Do Chinese domestic firms benefit from FDI inflow? Evidence of horizontal and vertical spillovers. China Economic Review, 20(4), 667-691.

MacKinnon, J. G. (1996). Numerical distribution functions for unit root and cointegration tests. Journal of Applied Econometrics, 11, 601-618.

Mackinnon, J. G., Haug, A. A., \& Michelis, L. (1999). Numerical distribution functions of likelihood ratio tests for cointegration. Journal of Applied Econometrics, 14, 563577.

Matthews, K., \& Zhang, N. X. (2010). Bank productivity in China 1997-2007: Measurement and convergence. China Economic Review, 21(4), 617-628.

Newey, W. K., \& West, K. D. (1994). Automatic lag selection in covariance matrix estimation. Review of Economic Studies, 61(4), 631-653.

Park, J. Y. (1992). Canonical cointegrating regressions. Econometrica: Journal of the Econometric Society, $60,119-143$.
Phillips, P. C., \& Hansen, B. E. (1990). Statistical inference in instrumental variable regression with I (1) processes. Review of Economic Studies, 57(1), 99125.

Phillips, P. C., \& Perron, P. (1988). Testing for a unit root in time series regression. Biometrica, 75(2), 335-346.

Saikkonen, P. (1992). Estimation and testing of cointegrated systems by an autoregressive approximation. Econometric Theory, 8(1), 1-27.

Shih, V., Zhang, Q., \& Liu, M. (2007). Comparing the performance of Chinese banks: A principal component approach. China Economic Review, 18(1), 15-34.

Stock, J. H., \& Watson, M. W. (1993). A simple estimator of cointegrating vectors in higher order integrated systems. Econometrica, 61, 783-820.

Sturm, J. E., \& Williams, B. (2004). Foreign bank entry, deregulation and bank efficiency: Lessons from the Australian experience. Journal of Banking and Finance, 28(7), 1775-1799.

Tan, Y., \& Floros, C. (2013). Risk, capital and efficiency in Chinese banking. International, Financial Markets, Institutions \& Money, 26(C), 378-393.

Xing, Y. (2006). Why is China so attractive for FDI? The role of exchange rates. China Economic Review, 17(2), 198-209.

$\mathrm{Xu}, \mathrm{Y}$. (2011). Towards a more accurate measure of foreign bank entry and its impact on domestic banking performance: The case of China. Journal of Banking \& Finance, 35(4), 886-901.

Yao, S., \& Wei, K. (2007). Economic growth in the presence of FDI: The perspective of newly industrializing economies. Journal of Comparative Economics, 35(1), 211-234.

Yao, S., Han, Z., \& Feng, G. (2008). Ownership reform, foreign competition and efficiency of China commercial banks: A non-parametric approach. The World Economy, 31(10), 1310-1326.

Ye, Q., Xu, Z., \& Fang, D. (2012). Market structure, performance, and efficiency of the Chinese banking sector. Economic Change and Restructuring, 45(4), 337-358.

Zhang, J., Wang, P., \& Qu, B. (2012). Bank risk taking, efficiency, and law enforcement: Evidence from Chinese city commercial banks. China Economic Review, 23(2), 284-295.

Zhou, X., Li, K. W., \& Li, Q. (2011). An analysis on technical efficiency in post-reform china. China Economic Review, 22(3), 357-372. 